\title{
Use of Social Networks of Lab Genomma as Important Key to Growth Hernández JGV*
}

Centro Universitario de Ciencias Económico Administrativas, Universidad de Guadalajara Periférico Norte 799; Los Belenes; C.P. 45100, Zapopan, Jalisco, México

\begin{abstract}
Mexican society is characterized by a tendency to self-medication when they get sick and be loyal to the brand that worked. Genomma Lab realized it and used its resources (including networks of social relations) to quickly positioned itself as the leader in the market with most of its brands in OTC medicines and products for health care. The article discusses how their beginning in publicity and the dynamism of their abilities makes him have a growth rate accelerated to the company.
\end{abstract}

Keywords: Genomma lab; Resource-based view; Marketing; Network; Competitive advantage

\section{JEL: L14, L65, M31, O43, O54}

\section{Introduction}

The OECD estimated that Mexico was the 2nd member country with the highest spending on medicines [1] but not only that, it is also a country that tends largely to self-medication and that if a product works for people, they will continue using for long. Just these two features has been a key determinant of the success of Genomma Lab, but that was not the only thing that was enough for the company to grow in such an accelerated way and to position itself as a leading brand with over 20 products on the market Mexican. Genomma Lab dabbled in a mature market, which was dominated by foreign companies. The firm has taken firm steps towards growth and internationalization, through an unconventional strategy of communication with their customers. It went from being considered an "ethnic" product to the shelves of products for personal care and OTC medications (OTC called by its acronym in English over the Counter) in the United States. The company is growing at an average $30 \%$ annual of international operations; besides being the only Mexican laboratory listed on the Mexican Stock Exchange. In this paper an analysis is presented of how is that Genomma Lab has taken the opportunities that are presented to reach the place where it is positioned today. The analysis could be approached from different successful perspectives, starting with the institutional vision, transaction costs incurred (and avoid incurring) the company. But it will be from the perspective of network strategy and mainly from the theory of resources and capabilities to be attached to the cunning with which the firm has used its networks to advertising the key to his success.

\section{Definition of the Problem}

From the point of view of the volume of money moving in different industries around the world, the pharmaceutical industry represents one of the four most productive in the current scenario, as [2] sustains, along with the sex industry, guns and illegal drugs. Because of the importance of the industry in the life of people, is that it highlights the usefulness of knowing the role Genomma Lab in the market industry. The pharmaceutical industry is engaged in the research, development and marketing of chemicals used in the treatment and prevention of diseases. According to the Ministry of Health [3] it may be prescription drugs or over-the-counter (OTC), patent medicines, and generic medicines, with the same active substance as the patent or similar drugs. (Figure 1) Many companies in the industry rely heavily on patent medicines. What they really need is to expand is its range of products or entering different niche markets, such as products for health care. However, the sector is one of the most profitable in the world. It has large corporations that invest large sums of money in research and development for the industry to continue to grow. Mexico has in its territory with 14 of the top 15 pharmaceutical companies worldwide. It is one of the major manufacturing centers in the world. According to figures from INEGI [4], the industry represents on average $1.2 \%$ of GDP and $7.2 \%$ of manufacturing GDP. The Secretary of Economics (SE) foresees that the over the counter medications have a growth of 3.2\% from 2013 to 2017. Among the leading companies in this segment are Bayer, Genomma Lab and Mondelez International, among others. And in 2012, Mexico was the main exporter in Latin America in the pharmaceutical industry; its companies are located

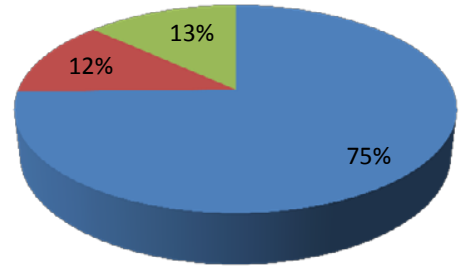

Medicamentos de
Patente
Medicamentos
Genéricos
Medicamentos sin
prescripcion

Figure 1: Sold medicines in Mexico.

*Corresponding author: José G. Vargas-Hernández, M.B.A.; Ph.D., Centro Universitario de Ciencias Económico Administrativas, Universidad de Guadalajara Periférico Norte 799; Los Belenes; C.P. 45100, Zapopan, Jalisco, México, Tel: +523337703340, Ext: 25685; E-mail: jvargas2006@gmail.com

Received November 07, 2014; Accepted February 10, 2015; Published February 20, 2015

Citation: Hernández JGV (2015) Use of Social Networks of Lab Genomma as Important Key to Growth. J Glob Econ 3: 134. doi:10.4172/2375-4389.1000134

Copyright: (c) 2015 Hernández JGV. This is an open-access article distributed under the terms of the Creative Commons Attribution License, which permits unrestricted use, distribution, and reproduction in any medium, provided the original author and source are credited. 


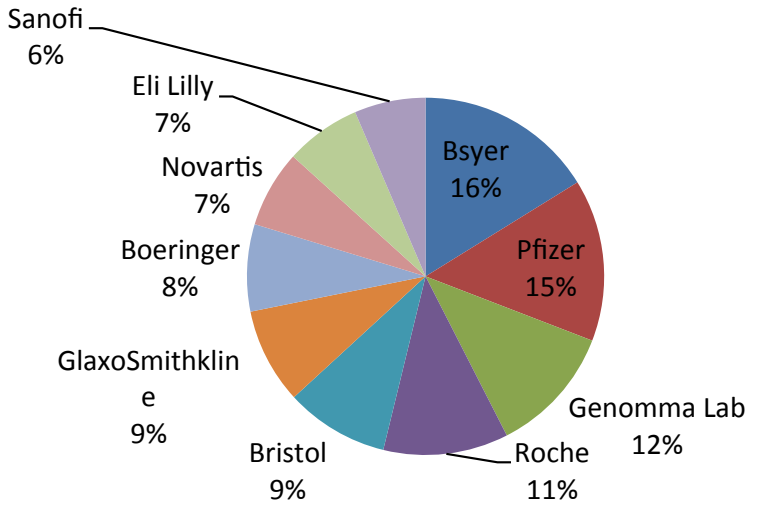

Figure 2: Sales in México in 2012(MDD).

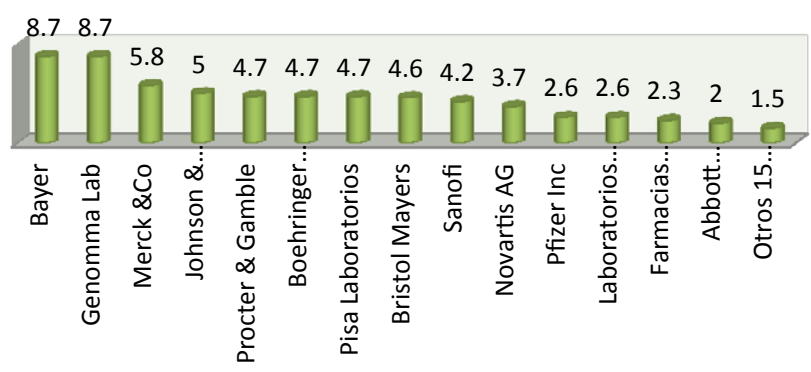

Figure 3: Percentage of market share of OTC products in 2012 Source: Data from Proméxico, 2013 compilation

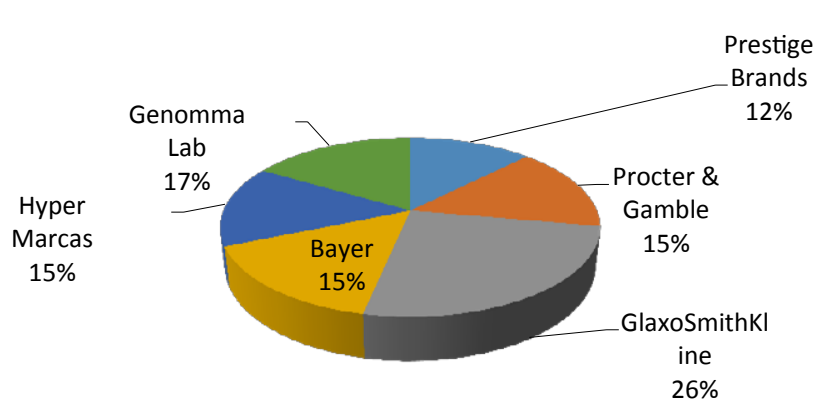

Figure 4: Gains from sales of personal care products.

mainly in the Federal District, Jalisco, Estado de Mexico, Puebla and Michoacán. The higher sales are shown in (Figure 2), where you can appreciate Genomma Lab as one of the most profitable among laboratories who live in Mexico. According to IMS Health [3], the market for non-prescription medicines is worth 134,740 million pesos in Mexico. It's the kind of more attractive to pharmaceutical product, since Mexicans tend largely to self-medication and, if a product reaches its functions, the consumer will continue using it for a long time and also will recommend them, i.e., it will be true to the brand. It must not be forgotten that the industry of OTC and personal care are the strengths of the company, are the markets that have significant market share compared to companies that already have more years in the same (Figures 3 and 4). These figures indicate that Genomma Lab then has an enviable share of the pharmaceutical market, the reasons that are conducive to giving rise to the research questions and assumptions of this article.

\section{Research question}

Genomma Lab takes advantage of network strategy for advertising and achieve growth and market positioning?

\section{Research assumption}

Genomma Lab leverages its external social networks for its advertising and therein lies its success.

\section{Theoretical and Conceptual Background}

The way in which a company operates has to do with how it behaves according to the industry to which they belong, but within that industry firms differ from one another individually. It was on this basis that it was proposed the theory of resources and capabilities [5-6] which recognizes the fact that companies use their resources to gain competitive advantage and based on them to better exploit their environment that competitors. Nevertheless, these advantages must have certain characteristics called the frame VRIO [7]. According to this framework, resources and capabilities of the company should be those that add (V) Value: value added resources and are constantly updated and not stagnate on irrelevant issues; (R) Rarity: if the resources that are common to the company has achieved the most you regarding its competition will be at its level, but never be surpassed by the competition; (I) Imitation: that competitors find difficult to copy the resources and capabilities that the company has and $(\mathrm{O})$ Organization: all resources, even if they are valuable, rare and difficult to imitate need to be under proper organization [8] specified that those resources are used in the production or generation of the service to which the company is engaged; while capabilities are the skills of the company to convert these resources into sustainable competitive advantages, i.e., the ability of the company to combine those resources properly are capabilities [9]. So it is a theory that should be seen mainly from two stages: the first one relates to obtaining such resources to enable it to develop and the second step when the company coordinates and manages these resources in the most effectively and efficiently. According to [10] in any market companies must find or create themselves a competitive advantage, a number of features that differentiate them from their competitors and lead to successfully meet their objectives, but also to be flexible and sustainable competitive advantage to cope with market changes. The activity of a business depends largely on the decisions they make and how they make those decisions, which are also influenced by the specific attributes that tell that person that influences significantly since the creation process of the company [11]. Among those attributes the firm has, one of the most important, and can be seen from the resource and capabilities theories are the networks of social relations, as companies are favored by the relationships that the employer has from the beginning, but also the ones which develops. It is a fact that entrepreneurs with more extensive social networks are more likely to identify further opportunities and seize them, for the same networks will mean a chance $[12,13]$. These networks can benefit him in many ways: financial support, professional advice and even moral support when needed both the company and its employer [14].

\section{Literature Review}

Following the theme of the importance of entrepreneurial networks to the entrepreneur, [15] found that companies founded by entrepreneur teams and no for only an entrepreneur are mostly intended 
for their company's success, mainly thanks to the social network a group will be much greater than the social network of an individual. As mentioned, the social network is a key factor for the success of a company, and this is not only crucial at the beginning, it is a fact that in the companies, a transfer of personal networks to organizational networks [7] is performed. The key is to not lose sight that the networks "help entrepreneurs identify international opportunities, establish credibility, reduce input costs and risks associated with internationalization" [15]. According to [16] what a company should do, speaking of marketing used, is to have the cheapest product (Cost), offering the best product (quality) or, adapt the offer to the customer (focus). It is the third option that best fits the present investigation, as the company adapts its advertising strategies so that the product is also suitable for its target audience [17] has stated that SMEs start their marketing strategies through the use of their social network of personal contacts. A good use of these personal contacts can lead the SMEs to a structure having greater flexibility and capacity to meet the challenges of their environment through cooperation allowing them to make more appropriate decisions. In Bogota, Colombia, a study found that GM Colomotores directed its advertising strategies in a different way. It was performed with more flexibility over its competitors and gave a substantial competitive advantage in its market [18].

\section{Contextual Framework}

\section{A. Origins of Genomma Lab}

Genomma Lab [19] is described as a company dedicated to the development and marketing of pharmaceutical and dermo-cosmetic products to improve the quality of life and health of society. The Company is currently involved in the OTC pharmaceutical market, the market for personal care products and generic drugs market. It is the only Mexican pharmaceutical company listed on the Mexican Stock Exchange since June of 2008, 12 years after its founding. The company started its career in 1996. Rodrigo Alonso Herrera Bagheria, its founder and current Chairman of the Board and CEO, began as Producciones Infovision's and was dedicated to the production of infomercials on television. The next year he began to develop its first products and use their connections in the television industry. Today is the first pharmaceutical company in the sale of OTC medicines and occupies the third position in the sale of generic drugs in the country with its brand for its First Level Health.

\section{B. Its market share}

The company increased its sales by $42 \%$ from 2009 to 2010 , i.e. 6236.6 million, and over the years has had a growth rate more or less the same magnitudes (Figure 5). Genomma Lab [20] offers more than 90 products in different categories with high growth, because according to IMS Health [3], the categories of anti-acne, fading scars, treatment for hemorrhoids, anti-ulcer, topical products ant varicose and muscles /skeleton, have grown at an annual rate of $61.1 \%$ from 2004 to 2007 (Figure 6) also foresees that OTC medicines will have a rate of $3.2 \%$ annual growth from 2013 to 2017, and Genomma Lab is already among the leading pharmaceutical companies in this segment. In the Top 20 products that contribute most to the OTC market in Mexico, there are five products Genomma Lab: Next, QG5, Dalay, Ultra Bengue and Sen. MetabolTonics (Figure 7) (Table 1).

\section{The strategy}

Genomma Lab [20] attributes its success to four main areas:

A. Manufacturing with high quality standards and high

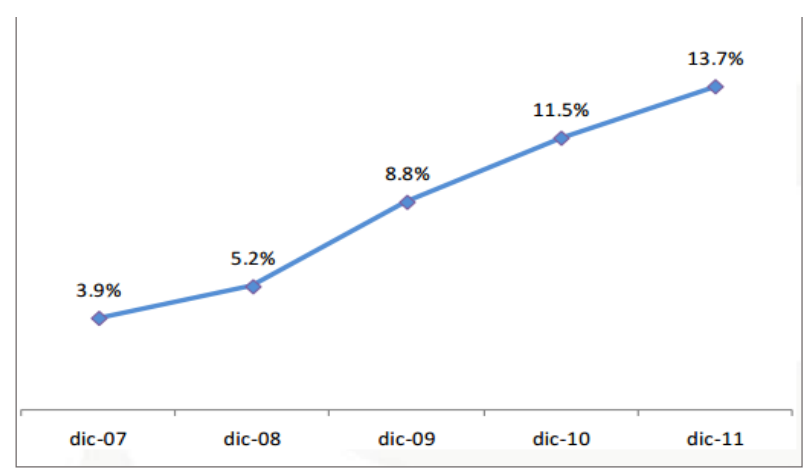

Figure 5: Growth in market share.

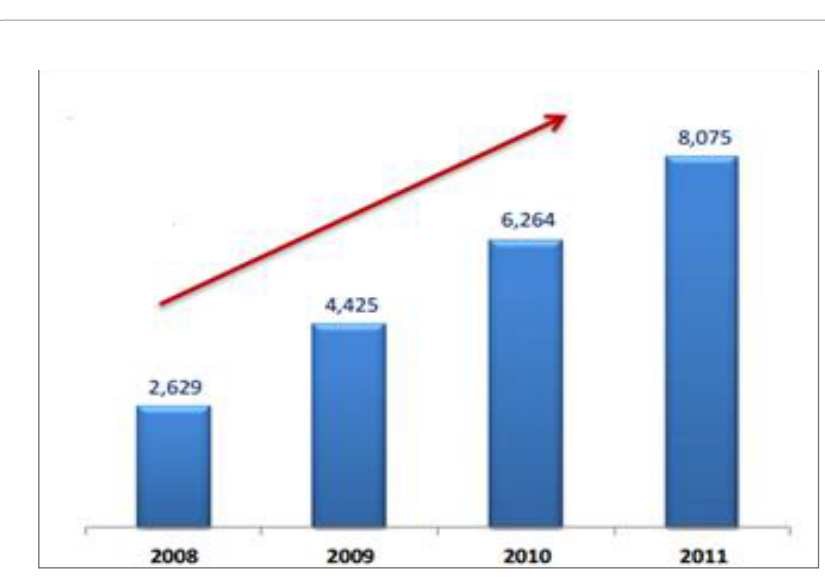

Figure 6: Net Sales.

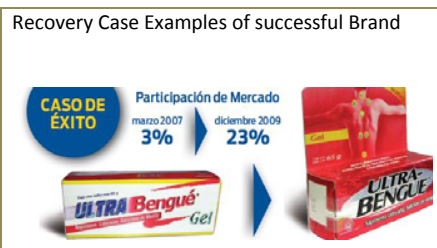

After its purchase, had improved their formula, launch an advertising campaign and within

two years, Bengue positioned as the brand leader in anti-rheumatic treatments Mexico.

Figure 7: Own elaboration with data from Genomma Lab (2014).

technology. To maximize the competitiveness and efficiently use of its economic resources, contracts with third parties to manufacture nearly all products.

B. Quality policy based on high international standards and strict quality controls.

C. Distribution and strong presence in retail outlets to be accessible to the consumer. 


\begin{tabular}{|c|c|c|}
\hline \multirow{4}{*}{$\begin{array}{l}\text { Distribution } \\
\text { channels }\end{array}$} & 24,000 pharmacies and samall commercial premises & $36.5 \%$ of sales \\
\hline & 2,891 supermarkets & $33.1 \%$ of sales \\
\hline & 3,094 pharmacy chains & $11.5 \%$ of sales \\
\hline & $\begin{array}{l}\text { 13,021 other outlets (convenience stores, } \\
\text { department, etc.) }\end{array}$ & $18.9 \%$ of sales \\
\hline \multirow[b]{2}{*}{ Sales 2012} & \multicolumn{2}{|l|}{$\$ 9,799.69$ million of pesos } \\
\hline & \multicolumn{2}{|l|}{$\begin{array}{l}73 \% \text { in México } \\
27 \% \text { internationally }\end{array}$} \\
\hline Sales 2013 & \multicolumn{2}{|l|}{$\$ 8,066.4$ million of pesos } \\
\hline Sales 2014 & \multicolumn{2}{|l|}{$\$ 2,438.2$ million in the first 4 months. } \\
\hline
\end{tabular}

Table 1: Some important figures Genomma Lab

D. Advertisement in all product launches with strong and innovative campaigns. To do this, it has its own team of designers, production and post-production of commercials.

The company also acquired brands that are known in the market in the area of personal care, healthcare and pharmaceuticals, but little is known about their situation; invests in advertising, improve image and sometimes some improvements to the formula it has been very good in its sales (Figure 7).

\section{Its networks of social relations}

Genomma Lab is the most powerful company in its field. It is linked from the beginning to the media [21]. This is easily verified relations with some of its most important figures.

A. The Executive Vice President of Business Expansion and Human Capital, Alejandro Bastón Patiño is brother of Joseph Bastón Patiño, president of Television and Content from Televisa.

B. Corporate Vice President of Genomma Lab, Neme Ramon Sastre, is related to leaders of the Institutional Revolutionary Party (PRI) and the Green Ecological Party of Mexico (PVEM).

C. The vice president of operations is Patricia Faci Villalobos, former president of the National Chamber of the Pharmaceutical Industry.

\section{E. Its advertising}

According to a study of large companies in Mexico and their advertising [22] found that the pharmaceutical Genomma Lab is the company whose advertising costs weighed more about their sales compared to firms in other sectors, mainly due to that it was not qualified against a direct competitor, because the company does not compete in only one sector. Therefore, its only comparative figures with other companies were taken.

An analysis on Mexican television [23] found that the most repetitive ads were mainly Genomma Lab. Out of the 21 most advertised products, 12 belong to the pharmaceutical (Figure 8) Comparison of the advertising intensity of Genomma Lab [22] Reps by brand in a onehour program for a week.

\section{Method}

To carry out the paper a method of mixed analysis was used to describe and explain the qualitative characteristics of the company. But also it was used the quantitative method, considering some sales figures, expenses and company growth (quantitative data) promote better understanding of the current situation in the market Genomma $\mathrm{Lab}$ as a result of its distinctive features.

\section{Analysis of Results}

While it is true that Genomma Lab has had impressive growth in its sales since the beginning of its operations, it has not reached it in vain. The company invests large amounts of its capital in the acquisition of recognized products and advertising campaigns which gain position in the consumer's mind. That gives a very significant competitive advantage over other companies that prefer to locate their focus of attention in less visible and conspicuous in the eyes of consumer's aspects. To achieve this, the company has taken advantage of external social networks that account by some of its more important collaborators and partners to leverage every opportunity it has had about as grabbing advertising space, even with the First Level for Your Health infomercials that specifically refer to its product brands for health conditions that a large proportion of society has. Far from marking the same name, Genomma Lab is not just a laboratory, it is a company fully committed to the use of marketing related techniques to sell products which, although they are in the pharmacy field, they are not properly developed by the company. Thus, its most important activity is the marketing. The Mexican population spends on average 2 hours and 52 minutes per day watching television and $63 \%$ of that audience focuses on Televisa [24], which certainly knows Genomma Lab and leverages its favor by its networks. It is difficult, as already stated, Genomma Lab to classify within a specific niche or a specific sector other than pharmaceutical, because its qualities are varied, always using that feature Mexican consumers especially have: making decision personally without the intervention of professionals in this specific case, the self-medication of Mexicans (and society in general to a lesser extent) [25] by their degree of mistrust between them significantly benefit the development of some companies [26] (Figure 9).

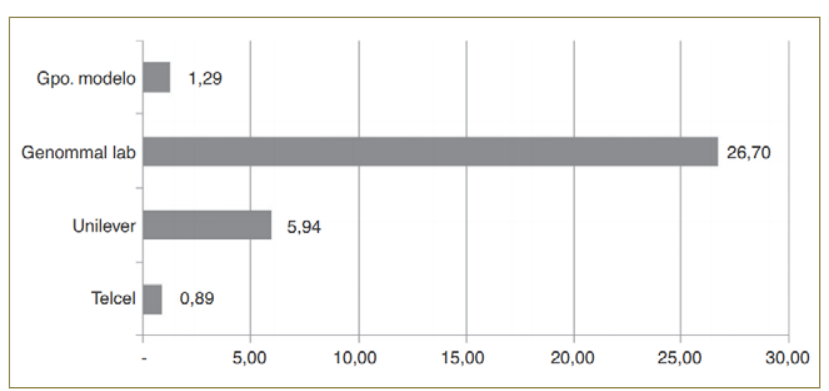

Figure 8: Comparison of the advertising intensity of Genomma Lab.

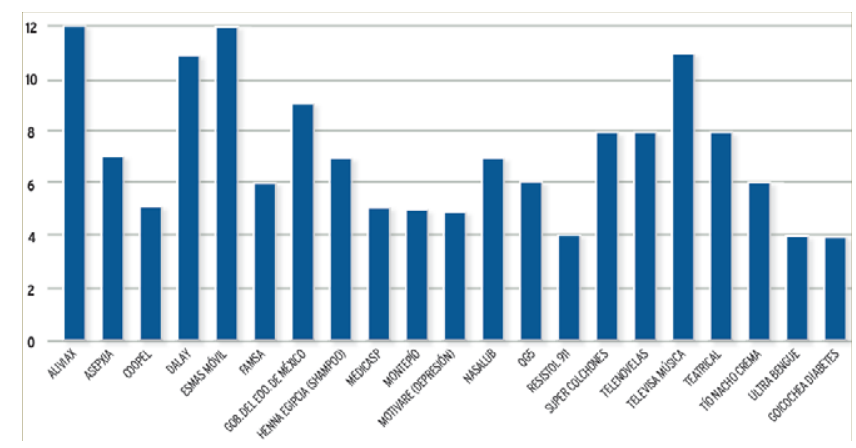

Figure 9: Reps by brand in a one-hour program for a week. 
Citation: Hernández JGV (2015) Use of Social Networks of Lab Genomma as Important Key to Growth. J Glob Econ 3: 134. doi:10.4172/23754389.1000134

Page 5 of 5

\section{Conclusions}

The beginnings of Genomma Lab as a company dedicated to advertising marked the trend that the firm would continue throughout its history [27]. Use this resource has been the cornerstone of the success of the business, from the production of its own business, owning its own production, recovery of products that somehow were forgotten on a shelf are just some of the positive consequences of the property that its founder has injected to the company from the beginning. It is from this vision of ITS advertising skill that the company has made it to where it is and continue to grow steadily and protruding from between companies $[28,29]$. A company that dared to dive into a market that looked like it would be dominated always by foreigners, but NOT only managed to enter but also to start unseat them in some niche markets should be an example to follow. That's where the resource and capabilities theory is totally immersed in practice [29]. Genomma Lab already had its resources; it knew advertising, knew key characters to follow developing resources and also knew how to perform a perfect combination of both, its capabilities to be successful.

\section{References}

1. Amoros J, Etchebarne S, Felzenstztein C (2012) International entrepreneurship in Latin America: Development challenges. Esic Market Economic and Business Journal 43: 497-512.

2. Barney J (1991) Resources of a firm and constant competitive advantages. Journal of management 17: 99-120.

3. CNN-Expansión (2013) The 500 most important companies in Mexico 2012.

4. CNN-Expansión (2014) Earnings and Sales of Genomma Lab suben. México.

5. Cruz I (2014) Economies of scale in large advertising companies in Mexico 2008-2011. Management studies 30: 3-9.

6. De Castro J (2008) Entrepreneurship and economic development: chiaroscuro of an ambiguous relationship. In Coduras, A. and Cross, C. (2008). The nature of the entrepreneurial process in Spain in the international context. Madrid, BBVA Foundation.

7. Díaz A (2012) Mexico, second OECD country with the highest spending on medicines.

8. Genomma Lab (2012). Annual Report 2012. Genomma Lab Internacional: Mexico.

9. Genomma Lab (2014).
10. Guerrero-Ortiz L, Montoya-Dávila A, Rodríguez-Solís L, Sierra JV. ManzanoOrtiz C (2011) Television and programming strategies for selling audiences Mexico. Case Study: Talk Show of Laura Bozzo. Ciencia Uat. 21, 8-13. ISSN 2007-0624.

11. INEGI (2009) Economic Census.

12. IMS Health (2014).

13. Luer C (2012) The 3 best ways to develop a competitive advantage. Merca2.0.

14. Molina D (2011). Conceptual framework on the determinants of interrelationships of SMEs. Projects Magazine. \# 5: 9-28. Digital ISSN: 2346-2167

15. Ortega P, Mc Phail E, Vega A (2011) Miracle Products and Media in Mexico: a critical reflection. Right to Communicate. Num. 3.

16. Padilla J (2014) The pharmaceutical industry and the global world.

17. Peng M (2010) Global strategy $2^{\mathrm{a}}$ ed. Cengage Learning. México.

18. Farma PM (2014) Genomma and Merk won by self-medication. PMFarma Iberoamerican Portal of Pharmaceutical Marketing.

19. Porter M (1991) Towards a dynamic theory of strategy. Strategic Management Journal 12: 95: 117.

20. Proméxico (2013) Pharmaceutical Industry. Proméxico, Business Intelligence Unit. Mexico.

21. Quintana C (2001) Dimensions of successful entrepreneurial companies. European Research Management and Business Economics 7: 139-158.

22. Rivera H (2014) Advertising, media to create a competitive advantage. Case Study. Universidad del Rosario, Bogotá.

23. Shane S, Locke E, Collins C (2003) Entrepreneur motivation. Human Resource Management Review 13: 257-279.

24. Secretaría de Salud (2014) Interchangeable Generic: verifiable quality at a lower price.

25. Schumpeter J (1934) The theory of economic development. Cambridge, Mass. Harvard University Press.

26. Televisa (2008) Audience analysis. Business Plan 2008.

27. Tyler B (2001) The complementarity of cooperative and technological competencies: a resource-based perspective. Journal of Engineering and Technology Management 18: 1-27.

28. Vos Saz A (2013) Creation, growth and international expansion of new companies: Influence of entrepreneurial and enterprising team. Unpublished Doctoral Thesis, University Carlos III of Madrid.

29. Wernerfelt B (1984) A Resourced-Based View on the Firm. Strategic Management Journal 5: 171-180. 